\section{Medical Research in Sweden}

A commitree of Swedish experts has drawn up plans for the establishment of a Central Council for Medical Research, and the granting of yearly allocations of $\mathrm{Kr}$. 1,000,000 for medical research. The committee recommends that the annual sum of Kr. 400,000 should be granted for medical research at the Universities of Uppsala and Lund, the Caroline, Odontological and Veterinary Institutes, and that Kr. 600,000 should be put at the disposal of the Council. As projected, the sum of $\mathrm{Kr} .400,000$ is to be divided among the five university colleges every year. Further, the sum of Kr. 135,000 would be used for bursaries of $\mathrm{Kr}$. 5,000 each for students' theses on medical and related subjects. The Council would, among other things, have the task of organizing collaboration between scientific men working on research in natural science and medicine.

\section{Summer School in Social Biology}

Aт the Summer School in Social Biology which the British Social Hygiene Council (Tavistock House North, Tavistock Square, London, W.C.1) will be holding at University College, Nottingham, during July 28-August 11, interest will be directed chiefly to problems of education and social life likely to arise through the coming increase in the schoolleaving age. The director of the School will be Prof. Winifred Cullis. The School is open to teachers, social workers and members of the general public interested in education and social problems from a biological angle. The morning lecture programme has been planned to illustrate the aims and content of social biology. Tea-time discussions will be reserved for subjects concerned with actual classroom problems of teaching social biology. In addition, an elementary course in the dissection of certain animal types will be available for those teachers who make special application. At the evening sessions lectures will be given by a distinguished group of visiting speakers on the broader application of biological knowledge to human life and culture. Acceptances to speak have been received from Prof. T. H. Pear, Sir Drummond Shiels, Dr. Otto May, Father Leycester King, Dr. Glover and Dr. David Mace. One special feature of the Summer School will be the Sunday sessions, at which lectures and discussions will be held upon the relation of biological science to "higher values and spiritual life". Further informa. tion about the School can be obtained from the Secretary, British Social Hygiene Council, Tavistock House North, Tavistock Square, London, W.C.I.

\section{South-Eastern Union of Scientific Societies}

THE fiftieth annual congress of the South-Eastern Union of Scientific Societies will be held this year on July 7 at Harpenden, the headquarters being at the Rothamsted Experimental Station. The presidentelect is Dr. W. G. Ogg, who will speak on some aspects of the work at Rothamsted, of which he is director. The sectional presidents and their addresses are: Mr. Edward Yates (archæology), "Church Chests" ; Dr. W. E. Brenchley (botany), "Trace Elements"; Mr. P. Evans (geology), "Some New Weapons in the Geological Armoury"; Dr. C. S. Orwin (social science), "Country Planning"; Dr. E. S. Russell (zoology), "Fishing Research and the Overfishing Problem". The honorary general secretaries of the Union are Mr. A. Farquharson and Mr. F. J. Epps, 78 Dunwich Road, Bexley Heath.
University of London Appointments

DR. A. B. HrLL, since 1933 University reader in epidemiology and vital statisties at the London School of Hygiene and Tropical Medicine, has been appointed to the University chair of medical statistics tenable at the School, as from October 1. During 1939-42 Dr. Hill was in charge of the Statistical Section in the Research and Experimental Depart. ment of the Ministry of Home Security, and since 1934 he has served part-time on the staff of the Medical Directorate of the Royal Air Force and was appointed consultant in medical statistics to the Royal Air Force.

Dr. Karl R. Popper, since 1937 senior lecturer in philosophy at Canterbury College, New Zealand, has been appointed to the readership in logic and scien. tific method tenable at the London School of Econ. omics, as from October 1.

The title of reader in organic chemistry in the University of London has been conferred, as from October 1, on Dr. E. R. H. Jones, in respect of the post held by him at the Imperial College of Science and Technology.

\section{Television-Past and Future}

IN the account in Nature of May 26 of an address by Mr. H. L. Kirke, the statement is made (p. 622) that a mobile transmitter was "developed by the B.B.C." for supplying outside broadcast television features. Mr. Kirke writes stating that the script of his lecture read: "the pioneer development work in the use of Post Office cables in this way was done by the B.B.C.". He adds, "the development of the mobile transmitter was undertaken by Messrs. E.M.I., although I did not actually mention this in my lecture or in the script."

\section{Announcements}

Sir Peirson Frank, chief engineer of the London County Council, has been elected president of the Institution of Civil Engineers for 1945-46.

AT the annual general meeting of the Institute of Physics, held on June 4, the following were elected to take office on October 1, $1945:^{\circ}$ President, Sir Frank Smith; Vice-President, Prof. A. M. Tyndall; Honorary Treasurer, Major C. E. S. Phillips ; Honorary Secretary, Prof. J. A. Crowther ; Ordinary Mem. bers of the Board, Dr. B. P. Dudding, Mr. A. J. Maddock, Prof. W. Sucksmith and Dr. C. Sykes. Prof. C. T. R. Wilson was elected an honorary fellow of the Institute.

Messrs. Newton Chambers and Co., Ltd., are providing the South Yorkshire Section of the Royal Institute of Chemistry with a sum of $£ 100$ per annum. for five years for the award of an annual prize for contributions to the subject of chemistry and industrial welfare. The 1945 competition is open to any fellow, associate or registered student of the Institute who had not reached his thirty-sixth birthday by January 1,1945 , and the award is offered for an essay, paper or papers, published or umpublished, embodying the candidate's own observations, or experimental work, on some aspects of the application of chemistry to the promotion of industrial welfare. A critical examination of existing knowledge is admissible, provided that the conclusions reached constitute an addition to the knowledge of the subject. Papers must reach the honorary secretary of the South Yorkshire Section, Royal Institute of Chemistry, c/o Newton Chambers and Co., Ltd., Thorncliffe Works, Sheffield, by December 31, 1945. 